\title{
To use or not to use teenage Afrikaans in HIV prevention messages directed at Afrikaans teenagers in Pretoria ${ }^{1}$
}

\author{
Elvis Saal \\ Department of Afrikaans and Theory of Literature, University of South Africa, PO Box 392, Unisa, 0003, \\ Pretoria, South Africa \\ E-mail: saaleo@unisa.ac.za
}

\begin{abstract}
The high HIV prevalence among young people makes them a prime target for HIV prevention campaigns, such as South Africa's "loveLife" campaign. One way to deliver documentmediated HIV messages directed at the youth is to use a language style to which they can relate. Drawing on the Communication Accommodation Theory and Language Expectancy Theory it is argued that teenagers are more likely to view the writer and the teenage variety favourably if they identify with the teenage variety in the print media. In this study two teenage slang versions of the same HIV message were examined. One version was an English teenage variety (hereafter the "loveLife variety") as used by loveLife in the print media. The other version was a teenage Afrikaans constructed by the Afrikaans teenagers themselves (hereafter "authentic teenage Afrikaans"). These two teenage varieties were not only compared to each other, but also to a standard Afrikaans version of the message. Two authentic teenage Afrikaans varieties - clearly running along the previous racial lines of "coloured" and "white" - were identified. This study indicates a generally unfavourable reaction to the (English) loveLife variety by both the Coloured Afrikaans and White Afrikaans teenage groups ${ }^{2}$. The Coloured Afrikaans teenagers viewed their authentic teenage Afrikaans (and the standard Afrikaans) very favourably and appropriate for HIV health communication. White Afrikaans teenagers viewed the use of their authentic teenage Afrikaans in document-mediated HIV messages as highly inappropriate.
\end{abstract}

Key words: teenage Afrikaans, health communication, Communication Accommodation Theory, language perceptions, speaker perceptions

\footnotetext{
${ }^{1}$ This paper is based primarily on research conducted for my $\mathrm{PhD}$ study.

${ }^{2}$ The terms "Coloured Afrikaans teenagers" and "White Afrikaans teenagers" are used here - for lack of a better term - to distinguish between the two groups of Afrikaans teenagers in the east of Pretoria. Afrikaans teenagers in the Eersterust suburb displayed a different slang lexicon and evaluative patterns from the Afrikaans teenagers in the Wilgers and Silverton suburbs. It so happens that the Eersterust suburb is still mostly a "Coloured" community, while the Wilgers and Silverton suburbs are mostly "White" communities. The terms "Coloured" and "White" are not used here to imply any racial prejudice, but are only used to distinguish between the two groups of Afrikaans teenagers in Pretoria.
} 


\section{Introduction}

The high HIV infection levels among young people in South Africa make them a prime target for health communication campaigns (such as loveLife) (see Shisana, Rehle, Simbayi, Parker, Zuma, Bhana, Connolly, Jooste and Pillay 2005). A significant challenge for campaigns like these is not only to determine what messages to include but also how to deliver these messages (Yzer 2008:53). Designers of documents associated with communication campaigns are often faced with the question of which language variety to use for greater effect when addressing teenagers about HIV/AIDS.

loveLife primarily uses an English teenage variety (hereafter the "loveLife variety") in their print-based communication campaigns. However, very little is known about teenagers' perceptions of the use of teenage varieties in document-mediated HIV messages. In this article, two teenage varieties are examined. Alongside the English loveLife variety, a second teenage Afrikaans variety was developed by the Afrikaans teenagers themselves (hereafter referred to as "authentic teenage Afrikaans"). These two teenage varieties were then compared to a standard Afrikaans version in terms of how participants perceive the language variety and writer.

Opinions differ as to the effectiveness of using non-standard varieties, such as teenage slang, in HIV messages. There are those who claim that using a language with which young people can associate may improve the reception of HIV prevention messages (Airhihenbuwa 1995:41). Others, such as Den Ouden and Van Wijk (2007:235), argue that teenage language is more appropriate in product advertisements than in health communication.

In this article, a theoretical framework for the type of language and speaker perceptions teenage language in HIV/AIDS health communication could evoke is first provided. Thereafter, the experimental study is explained, in particular how the authentic teenage Afrikaans version was developed by the participants themselves. This is followed by an exposition of the results and a discussion thereof. This article concludes with recommendations on how teenage Afrikaans could be used in print-based HIV messages when directed at Afrikaans teenagers.

\section{Teenage Afrikaans in the print media: some perceptions and language expectations}

It is often assumed that in order to reach or attract the attention or interest of teenagers one should speak to them in their own "lingo". It is therefore not uncommon to find a teenage Afrikaans in youth literature such as Jackie Nagtegaal's (2002) Daar's 'n vis innie punch, newspapers such as the Beeld-supplement Jip, youth magazines such as Hoezit, as well as radio programmes such as Tempo and Befonk on RSG (see Jacobs 2009:144-145). The occurrence of a teenage Afrikaans in health communication is still very limited, if any occurs at all. It would seem that teenage language is used more frequently for topics of a less serious nature, while for more serious topics, such as HIV prevention messages, standard Afrikaans is employed. However, it is doubtful whether the use of standard Afrikaans in HIV prevention messages will attract the attention of teenagers who already suffer from what is sometimes called "HIV information fatigue" (Levine and Ross 2002:96). The use of teenage language could therefore function as a clever ploy to attract teenagers to HIV health communication messages. Perception studies on teenage Afrikaans are, however, very limited. In fact, teenage 
Afrikaans in general has received very limited attention in sociolinguistic research (Marais and Coetzee 2005:245).

The use of a teenage Afrikaans in the Afrikaans print media (mockingly referred to as "Engfrikaans" - a mixture of Afrikaans and English) attracts very negative emotional reactions from Afrikaans (literary) scholars, journalists, academics and writers (see Jacobs 2009:145-146). However, very limited research has been conducted on how Afrikaans teenagers themselves view the use of their teenage Afrikaans in document-mediated communication. South African teenagers themselves have differing views on the use of their teenage language(s) in the print media. I found that Cape Afrikaans and Sepedi teenagers were more favourable towards the use of their teenage variety in document-mediated communication (whether a product advertisement or an HIV prevention message) (Saal 2011; Saal and Blignaut 2011). English-speaking teenagers, however, tend to view the use of their teenage variety in print-based HIV prevention messages as totally inappropriate and artificial (Saal 2011; see also Den Ouden and Van Wijk 2007 for a similar finding among Dutch teenagers).

To predict how Afrikaans teenagers will perceive the use of a teenage Afrikaans in health communication messages on HIV and AIDS is not as straightforward as the so-called "common perceptions" would indicate. According to the Language Expectancy Theory, language is a rule-governed system in which people develop certain expectations and norms about what constitutes appropriate language behaviour in certain contexts (Burgoon and Siegel 2004:149). If a speaker positively violates these expectations about what the appropriate communication behaviour should be, then the receiver's attitude about the advocated position may become more positive. If these expectations are negatively violated, the message will also be viewed unfavourably. A positive violation refers to when the language behaviour is better or more preferred than the expected language behaviour (Burgoon and Siegel 2004:151-155).

Print media is commonly associated with a more formal register, expressed by the use of the standard variety (Giles and Billings 2004:192). The use of a teenage Afrikaans in health communication on HIV and AIDS could violate teenagers' language expectations. However, it is far easier to predict whether an expectation will be violated than to predict whether the violation will be perceived in a positive or negative light (Bradac and Giles 2005:216). Den Ouden and Van Wijk (2007:245) argue that teenage language in document-mediated communication is not a "natural" relation, given that teenage slang is primarily a spoken variety. They found that Dutch teenagers perceive teenage language in product advertisements as unauthentic, forced, not credible and artificial (for a similar finding see Saal (2011) with regard to the English speaking teenagers). Therefore, on the basis of this, teenage slang in health communication would seem to be a negative violation of teenagers' language expectations. However, as alluded to earlier, Cape Afrikaans and Sepedi teenagers tend to have a much more favourable view of the use of their teenage variety in document-mediated communication. It is therefore not far-fetched to conclude that Afrikaans teenagers would most likely view the use of their teenage Afrikaans in an HIV prevention message as a fresh, light-hearted and even unexpected approach to a sensitive topic such as HIV, and in so doing, teenage Afrikaans could be viewed as a positive violation of teenagers' language expectations. 
In this study an authentic teenage text version was carefully constructed, in the sense that this version was created by the participants themselves. The chances that teenagers could view the authentic teenage Afrikaans as similar to theirs are therefore enhanced, making it more plausible that the teenagers could respond positively to the violation of linguistic norms - i.e. to have a favourable view of the use of their teenage Afrikaans in HIV prevention messages.

\section{Teenage Afrikaans and the perceived image of the writer}

The use of a teenage Afrikaans in print health communication could be an effective strategy to resemble the style of the teenage target group, thereby creating the feeling that the writer is an accepted member of the peer group and is "on the same wavelength" (Orme and Starkey 1999:8). In several health information programmes, language homophily has played an important role in reaching and positively influencing target populations (see Orme and Starkey 1999; Svenkerud and Singhal 1998). Studies have found that receivers with a strong social identity view speakers of their own group more favourably and were more socially attracted to them than to the out-group speaker (Bresnahan, Ohashi, Nebashi, Liu and Shearman 2002; Genesee and Bourhis 1988). According to De Klerk (2005:112), the use of a teenage slang could be a way not only to reinforce in-group membership, but also to accentuate intergroup differences, for example between teenagers who speak the lingo and those who do not, between teenagers and other adults, between teenagers and parents, etc.

The use of a teenage Afrikaans in print health communication is not only a linguistic means to construct a shared social identity with the teenage readers, but also to reduce the linguistic and social distance between the reader and writer. According to the Communication Accommodation Theory (CAT), when a receiver perceives the linguistic style of the speaker to be similar to his or her linguistic style, the social distance between the interlocutors is reduced and feelings of greater interpersonal attraction could follow (Gallois, Ogay and Giles 2005:125-126).

A teenage Afrikaans with which teenagers could identify is more likely to have positive repercussions for the writer's social attractiveness and in-group status.

\section{Teenage varieties employed in this study}

In this study two teenage varieties are examined. The first is the English variety (with its more American-orientated slang character expressed by words such as "getting around", "gal" and "playa") that is used by the loveLife organisation (cf. Appendix 1 for an example) - referred to as the "loveLife variety". The other teenage variety is a teenage Afrikaans that was developed by the participants themselves using their own teenage Afrikaans - referred to as "authentic teenage Afrikaans". Both of these teenage varieties are then compared to standard Afrikaans.

The teenage variety portrayed in the loveLife text could be a successful attempt to use the linguistic style of the target group. However, it could also be a classic example of what Coupland, Coupland, Giles and Henwood (1988:9-14) label "over-accommodation": the copywriter of the loveLife text may have thought that he or she was converging to the style of the reader, based on his or her perceptions and beliefs of the reader, while the reader may have perceived this quite differently. The writer of the loveLife text may have based his or her 
linguistic style convergence not on the actual language of teenagers, but on his or her beliefs, expectations, perceptions or stereotypes of where he or she thought the intended target audience was positioned linguistically (Gallois, Ogay and Giles 2005:126-127). The teenage readers may have found the loveLife variety to be inappropriate, patronising and condescending.

It is expected that the authentic teenage Afrikaans version would be seen as a better reflection of the intended target group's language style based on the fact that it was elicited from members of the target group themselves. The experimental set-up is driven by the following premises:

- Language perceptions: The teenage group will perceive the authentic teenage Afrikaans version as mirroring their linguistic style, and therefore view the use of the authentic teenage Afrikaans in the print media as a positive violation of their expected language behaviour.

- Writer perceptions: The teenage group is more likely to view the writer of the authentic teenage Afrikaans version as a teenager (an in-group member) and as socially attractive (i.e. someone they like).

\section{Method $^{3}$}

\subsection{Participants}

A total of 255 grade 11 participants from three Afrikaans-medium schools (Eersterust Sekondêr, Die Wilgers Hoërskool and Silverton Hoërskool) in the east of Tshwane participated in the study. The mean age of the participants was 17. The Afrikaans group was subdivided into two groups: a Coloured Afrikaans group $(\mathrm{n}=106$; female $=68.9 \%$, Male $=$ $31.1 \%)$ and a White Afrikaans group $(\mathrm{n}=149$; female $=53.7 \%$, male $=46.3 \%)$.

\subsection{Construction of stimulus texts}

As previously mentioned, an original loveLife text, written in English teenage slang, was selected as primary stimulus material (cf. Appendix 1). To determine which lexical items or expressions could be regarded as slang in the loveLife text, Probert Encyclopaedia's Online Slang dictionary and the South African Concise Oxford Dictionary (2002) were consulted. All words labelled "informal" in the dictionary were also regarded as slang lexicon. The loveLife teenage text was then translated into standard Afrikaans by replacing the words which were considered slang with more standard lexical items (cf. Appendix 2).

The standard Afrikaans text was then presented in a separate study to a random selection of grade 11 Afrikaans participants $(\mathrm{n}=75)$ attending the three previously-mentioned high schools. Participants were asked to translate the standard Afrikaans text into a more teenage Afrikaans version. The request was that they should only provide teenage slang equivalents if these existed.

In constructing the authentic teenage Afrikaans text, by using coding for frequency, it was evident that the slang items used by the participants from Eersterust Secondary School

\footnotetext{
${ }^{3}$ In this paper the methodology is based on research conducted for my $\mathrm{PhD}$ study and forms part of a wider experimental study.
} 
differed largely from those used by the participants from the Wilgers and Silverton High schools (see Table 1).

Table 1. Differences in lexical items between teenage learners from Eersterust and SilvertonWilgers high schools

\begin{tabular}{|l|l|l|}
\hline & Eersterust learners & Silverton-Wilgers learners \\
\hline rondslaap & rondbak & rondraps \\
\hline meisie & dol & chick \\
\hline baie & 'n gang & baie \\
\hline getalle & nommers & hoeveel \\
\hline $\begin{array}{l}\text { ander seksueel aantreklike } \\
\text { meisie of seun }\end{array}$ & different ntcha dol of ou & ander sexy chick of ou \\
\hline te slaap & te bak & te raps \\
\hline MIV/Vigs & Groot siekte & Aids \\
\hline baie beter & ntchaer & cooler \\
\hline
\end{tabular}

The first-language speakers of Afrikaans at Eersterust Secondary consisted mainly of Coloured learners, while at Wilgers and Silverton High schools they were mainly White learners. For this reason, two separate, authentic teenage Afrikaans versions were created one for the Coloured Afrikaans participants and one for the White Afrikaans participants (see Appendix 3, (a) and (b) respectively). The Afrikaans group was therefore subdivided into two groups: a Coloured Afrikaans group and a White Afrikaans group. Both these groups were exposed to three text versions, namely the loveLife variety, authentic Coloured Afrikaans teenage variety or authentic White Afrikaans teenage variety, and standard Afrikaans. The authentic Coloured Afrikaans teenage version was distributed among the Coloured Afrikaans participants only, while the authentic White Afrikaans teenage version was distributed among the White Afrikaans participants only.

Two separate experimental studies were conducted - one for the Coloured Afrikaans participants and one for the White Afrikaans participants. In both the Coloured Afrikaans and White Afrikaans groups, each participant was given only one of the three text versions (i.e. either the loveLife version, or the authentic teenage Afrikaans version or the standard Afrikaans text). As far as possible, the three text versions were distributed equally among both sexes. Participants were required to read the text only once and then complete 5-point rating scales and answer (open) questions relating to how they view the language variety and the writer.

\subsection{Questionnaire}

A combination of rating scales and open questions was employed to measure participants' perceptions of the language variety and the writer.

\subsubsection{Measuring language perceptions}

To measure whether participants perceived the teenage variety texts (i.e. the loveLife variety and authentic teenage Afrikaans) as a violation of their language expectations, a 2-item semantic differential scale was constructed. The reliability of the scale was not adequate ${ }^{4}$ in

\footnotetext{
${ }^{4}$ For a multi-item scale to be considered of adequate reliability, a Chronbach's alpha score of .65 and higher was required.
} 
both the Afrikaans groups (Coloured Afrikaans group: Cronbach's $\alpha=0.60$; White Afrikaans group: Cronbach's $\alpha=0.57$ ). These scale items were then entered separately in the univariate analyses. To determine whether the violation would be perceived as positive or negative, the close-ended question "Do you like the language used in the text?" was asked. If participants answered the question affirmatively, the violation was perceived as positive and if they answered the question negatively, the violation was perceived as negative. To investigate the reasons why participants would prefer a particular language variety, participants were asked to give one reason why they liked or disliked the language variety in question.

To measure participants' perceptions of the language use as similar to their own, a 5-item Likert-type scale was constructed. One item correlated negatively with the other items in the scale and was therefore omitted. The reliability of the scale was high in both groups (Coloured Afrikaans: Cronbach's $\alpha=0.80$; White Afrikaans: Cronbach's $\alpha=0.86$ ).

An open question was also included to determine whether the participants enjoyed reading the text. This was included to provide an overall view of how the text was perceived by the participants.

\subsubsection{Measuring the perceived image of the writer}

A single-item bipolar scale (adult - teenager) was used to measure the in-group status of the writer. To measure the social attractiveness of the writer, a close-ended question ("Would you regard the writer as friend?") was included to determine whether participants would be socially attracted to the writer. Participants were then asked to provide one reason for their answer to the close-ended question.

An open question on how participants would describe the writer of the text was also included. The keyword response method, used by Garrett, Coupland and Williams (2003:179), was used. Participants were asked to provide their first impressions of the writer by way of two keywords. This open question was included to allow participants the opportunity to express their opinions and feelings about the writer, which are not limited to specific characteristics. This provides for a richer, meaningful and more spontaneous evaluative profile of the writer (Saal 2008:139).

\subsubsection{Manipulation checks}

To check whether participants perceived the manipulations of the language variety as intended (i.e. as either being standard and formal or non-standard and informal), a 4-item bipolar scale was included, mainly based on scales constructed by Arthur, Farrar and Bradford (1974:257) and Burgoon and Hale (1987:36-37). The reliability of the scale was adequate in both groups (Coloured Afrikaans: Cronbach's $\alpha=0.65$; White Afrikaans: Cronbach's $\alpha=0.78$ ).

\section{Results}

\subsection{Manipulation checks}

The manipulations of the language varieties were successful in that these language varieties were perceived in the way that had been intended. Univariate analyses revealed a main effect for perceived language standardness/formal nature in both the Coloured Afrikaans group ( $F$ $\left.(2,103)=22.05, p<.001, \eta^{2}=0.30\right)$ and the White Afrikaans group $(F(2,146)=24.14, p<$ 
$\left..001, \eta^{2}=0.25\right)$. Planned comparisons revealed that in both groups, the standard Afrikaans version was considered more standard/formal than the non-standard variety versions (i.e. the loveLife variety and authentic teenage Afrikaans). An additional effect was found in the Coloured Afrikaans group in that these participants considered the loveLife variety version as more standard/formal than the authentic Coloured Afrikaans teenage version.

\subsection{Language perceptions}

Firstly, it was expected that participants would perceive authentic teenage Afrikaans as a positive violation of their expected language behaviour. Univariate analyses revealed a main effect for violation of language expectations in the case of the White Afrikaans group ( $F$ $(2,146)>6.26, p$ 's $\left.<0.01, \eta^{2}>0.08\right)$. In the case of the Coloured Afrikaans group, there was a trend towards an effect of language variety on violation of language expectations $(F(2,103)$ $=2.79, p=0.07)$. Planned comparisons revealed that in the case of the White Afrikaans participants, the non-standard varieties were considered more a violation of participants' language expectations than standard Afrikaans. In the case of the Coloured Afrikaans participants, there was a trend to perceive authentic teenage Afrikaans more a violation of their language expectations than standard Afrikaans. To determine whether this violation could be regarded as positive or negative, participants' responses to the close-ended question "Do you like the language used in the text?" were analysed (using the Chi square test).

Table 2. Frequency of participants' (dis)liking of the language variety

\begin{tabular}{|l|c|c|c|}
\hline & $\begin{array}{c}\text { loveLife variety } \\
{\left[\mathrm{n}^{1}=29\right]} \\
{\left[\mathrm{n}^{2}=46\right]}\end{array}$ & $\begin{array}{c}\text { Authentic } \\
\text { teenage } \\
\text { Afrikaans } \\
{\left[\mathrm{n}^{1}=50\right]} \\
{\left[\mathrm{n}^{2}=55\right]}\end{array}$ & $\begin{array}{c}\text { Standard Afrikaans } \\
{\left[\mathrm{n}^{1}=27\right]} \\
{\left[\mathrm{n}^{2}=47\right]}\end{array}$ \\
\hline Coloured Afrikaans ${ }^{1}$ & 23 & 41 & 24 \\
\hline Like the variety & 3 & 6 & 0 \\
\hline Dislike the variety & 3 & 3 & 3 \\
\hline Do not know & & & 28 \\
\hline White Afrikaans ${ }^{2}$ & 21 & 21 & 14 \\
\hline Like the variety & 15 & 22 & 5 \\
\hline Dislike the variety & 10 & 12 & \\
\hline Do not know & & & \\
\hline
\end{tabular}

It is evident that Coloured Afrikaans participants indicated a clear liking for all of the language varieties, although there was no significant effect for liking the language variety in both the groups (Coloured Afrikaans: $\chi^{2}(4)=4.00, p=0.41$; White Afrikaans: $\chi^{2}(4)=5.51$, $p=0.24)$. Coloured Afrikaans participants cited the following reasons most frequently for liking the language varieties:

loveLife variety

- Easy to understand (28\%)

- Relate to language $(21 \%)$

Authentic teenage Afrikaans

- The way we speak (54\%)

- Easy to understand (24\%) 
Standard Afrikaans

- Easy to understand (56\%)

- Similar language use (11\%)

White Afrikaans participants, on the other hand, tended to dislike the teenage varieties. They listed the inappropriateness of the teenage varieties as the most frequent reason for disliking the non-standard varieties (loveLife variety: 11\%; authentic teenage Afrikaans: 24\%)

Interestingly, there was no frequent commonly cited reason why participants would dislike standard Afrikaans. On the contrary, participants frequently indicated that they liked the standard Afrikaans version because it was easy to understand $(30 \%)$.

It would seem that White Afrikaans participants did not perceive their authentic teenage Afrikaans as a positive violation of their language expectations. In the Coloured Afrikaans group, their authentic teenage Afrikaans would seem to have the potential to be considered a positive violation of participants' language expectations.

Secondly, it was expected that participants would perceive authentic teenage Afrikaans to be more similar to their communication style than the loveLife or standard Afrikaans varieties. This was partially the case in the Coloured Afrikaans group. Univariate analyses revealed a main effect for similar language use in the case of the Coloured Afrikaans group $(F(2,103)=$ $\left.10.25, p<0.001, \eta^{2}=0.17\right)$, but no main effect in the White Afrikaans group $(F(2,146)<1$, $p=0.85)$. Planned comparisons revealed that Coloured Afrikaans participants perceived their authentic teenage Afrikaans and standard Afrikaans to be more similar to the way they speak than the loveLife variety. White Afrikaans participants tended to view all three language varieties as being quite dissimilar from their communication style.

Lastly, participants' overall impressions of the three text versions as enjoyable seem to differ in the two groups. More than $90 \%$ of the Coloured Afrikaans participants tend to find all three text versions equally enjoyable, while less than half of the White Afrikaans participants find the text versions enjoyable. The most commonly cited reasons for why participants enjoyed the texts are listed below.

Table 3. Most commonly cited responses for text appreciation

\begin{tabular}{|l|l|l|}
\hline & Coloured Afrikaans & White Afrikaans \\
\hline loveLife variety & $\begin{array}{l}\text { Learned something (62\%) } \\
\text { Interesting (17\%) }\end{array}$ & $\begin{array}{l}\text { Use of slang (11\%) } \\
\text { Interesting (17\%) }\end{array}$ \\
\hline $\begin{array}{l}\text { Authentic teenage } \\
\text { Afrikaansvariety }\end{array}$ & $\begin{array}{l}\text { Learned something (42\%) } \\
\text { Interesting (30\%) }\end{array}$ & $\begin{array}{l}\text { Learned something (13\%) } \\
\text { Interesting (20\%) }\end{array}$ \\
\hline Standard Afrikaans & $\begin{array}{l}\text { Learned something (32\%) } \\
\text { Interesting (22\%) }\end{array}$ & $\begin{array}{l}\text { Learned something (15\%) } \\
\text { Interesting (17\%) }\end{array}$ \\
\hline
\end{tabular}

Coloured and White Afrikaans participants tended to appreciate the texts mostly because of their educational content ("learn something new") and entertainment value ("it is interesting"). White Afrikaans participants listed AIDS fatigue ("tired of hearing about 
AIDS"; "hear too much about AIDS") as the most frequent reason for not enjoying the texts, irrespective of the language variety used.

\subsection{Perceived image of the writer}

Chi square tests conducted on the adult-teenager bipolar scale revealed that there was no significant effect of language variety on the in-group status of the writer in both groups (Coloured Afrikaans: $\chi^{2}(4)=5.99, p=0.19$; White Afrikaans: $\chi^{2}(4)=6.41, p=0.17$ ). White Afrikaans participants perceived the writer of the three text versions as an adult. The use of the authentic White Afrikaans teenage variety did not succeed in creating a teenage persona for the writer. Coloured Afrikaans participants were more divided on whether the writer is an adult or a teenager.

To determine whether participants would be socially attracted to the writer, participants' responses to the close-ended question "Would you regard the writer as a friend?" were analysed using the Chi square test.

Table 4. Frequency of participants (dis)liking the writer as function of the language variety

\begin{tabular}{|l|c|c|c|}
\hline & $\begin{array}{c}\text { loveLife variety } \\
{\left[\mathrm{n}^{1}=29\right]} \\
{\left[\mathrm{n}^{2}=46\right]}\end{array}$ & $\begin{array}{c}\text { Authentic } \\
\text { teenage } \\
\text { Afrikaans } \\
{\left[\mathrm{n}^{1}=50\right]} \\
{\left[\mathrm{n}^{2}=55\right]}\end{array}$ & $\begin{array}{c}\text { Standard Afrikaans } \\
{\left[\mathrm{n}^{1}=27\right]} \\
{\left[\mathrm{n}^{2}=47\right]}\end{array}$ \\
\hline Coloured Afrikaans & & 33 & 16 \\
\hline Like the writer & 17 & 3 & 0 \\
\hline Dislike the writer & 2 & 14 & 11 \\
\hline Do not know & 10 & & 11 \\
\hline White Afrikaans & & 14 & 16 \\
\hline Like the writer & 13 & 13 & 20 \\
\hline Dislike the writer & 13 & 28 & \\
\hline Do not know & 20 & & \\
\hline
\end{tabular}

There was no effect of language variety on the social attractiveness of the writer in both groups (Coloured Afrikaans: $\chi^{2}(4)=2.84, p=0.58$; White Afrikaans: $\chi^{2}(4)=1.66, p=0.80$ ). Coloured Afrikaans participants showed an overall liking for the writer, irrespective of the language variety used. The most commonly cited reason for wanting to befriend the writer was that "the writer gives good advice". White Afrikaans participants, however, were more uncertain whether they would want to befriend the writer. They listed the unfamiliarity of the writer ("I don't know the writer") as the most frequent reason for not wanting to befriend him/her.

The overall characteristics of the writer, by way of the keyword responses, are listed in Table 5 . 
Table 5. Most commonly cited characteristics of the writer (minimum 10\%)

\begin{tabular}{|c|c|c|}
\hline & Coloured Afrikaans & White Afrikaans \\
\hline loveLife variety & $\begin{array}{l}\text { Knowledgeable and experienced } \\
\text { person }(41 \%) \\
\text { Caring and understanding }(34 \%) \\
\text { Teenager }(28 \%) \\
\text { Adult }(21 \%)\end{array}$ & $\begin{array}{l}\text { Knowledgeable and } \\
\text { experienced person }(30 \%) \\
\text { Caring and understanding } \\
(20 \%)\end{array}$ \\
\hline $\begin{array}{l}\text { Authentic teenage } \\
\text { Afrikaans }\end{array}$ & $\begin{array}{l}\text { Caring and understanding }(40 \%) \\
\text { Knowledgeable and experienced } \\
\text { person }(34 \%) \\
\text { Teenager }(22 \%) \\
\text { Adult }(16 \%)\end{array}$ & $\begin{array}{l}\text { Knowledgeable and } \\
\text { experienced person }(33 \%) \\
\text { Caring and understanding } \\
(22 \%) \\
\text { Foolish, unwise, misguided } \\
\text { person }(13 \%) \\
\text { Honest }(11 \%)\end{array}$ \\
\hline Standard Afrikaans & $\begin{array}{l}\text { Caring and understanding }(44 \%) \\
\text { Knowledgeable and experienced } \\
\text { person }(33 \%) \\
\text { Teenager }(19 \%) \\
\text { Adult }(19 \%) \\
\text { Female }(19 \%)\end{array}$ & $\begin{array}{l}\text { Knowledgeable and } \\
\text { experienced person }(23 \%) \\
\text { Caring and understanding } \\
(26 \%) \\
\text { Friendly }(11 \%)\end{array}$ \\
\hline
\end{tabular}

\section{Discussion}

The results reflect different evaluative patterns for Coloured Afrikaans and White Afrikaans teenagers, specifically with regard to language perceptions.

\subsection{Language perceptions}

Coloured Afrikaans teenagers seem to have a positive perception of their use of teenage Afrikaans in health communication. In fact, they view the use of their (authentic) teenage Afrikaans (not the loveLife variety) in document-mediated health communication as a positive violation of their language expectations. Furthermore, Coloured Afrikaans teenagers identify with this written portrayal of their teenage language (i.e. their authentic teenage Afrikaans). This identification with their authentic teenage Afrikaans was based on affective grounds: Coloured Afrikaans teenagers viewed authentic teenage Afrikaans as "their own", and as "the way (they) speak". Their identification with standard Afrikaans, however, was seen as a cognitive construct: they liked standard Afrikaans because it was easy to understand (see also Saal 2003:104; Saal and Fredericks 2005:265). Coloured Afrikaans teenagers' visible lack of stigmatisation and negative stereotyping of their teenage Afrikaans in printbased HIV prevention messages defies the claim that teenage language in health communication is not a "natural" relation, that it is something unauthentic, forced, not credible and artificial. For Coloured Afrikaans teenagers, the use of their teenage Afrikaans could just be, as one participant put it, a way "to give more meaning to the message". Saal (2011) reports on a similar favourable evaluation of the authentic teenage variety by Sepedi teenagers. Coloured Afrikaans and Sepedi teenagers tend to be much more accommodative of their teenage variety in the print media. 
White Afrikaans teenagers, however, do not have a very positive view of the use of their teenage Afrikaans in HIV health messages. They did not identify with their authentic teenage Afrikaans despite the fact that different participants from the population were involved in the construction of the teenage and the pre-testing versions. Furthermore, White Afrikaans teenagers view the use of their teenage Afrikaans as a negative violation of their expected language behaviour. White Afrikaans teenagers generally do not like the use of teenage varieties in health communication messages. They view the use of the teenage varieties (i.e. the loveLife variety and the authentic teenage Afrikaans) in these print-based health messages as "unprofessional", "inappropriate", "not normal", using "too much slang", "make[ing] you sound stupid", "sounds[ing] like you don't care" and having "no class". White Afrikaans teenagers seem to be more aware of situational norms and tend to apply these norms more strictly, therefore any deviations from the norm are more negatively evaluated. They perceived the topic of promiscuity as a formal and serious issue which needs to be dealt with in a serious manner, hence the preference for standard Afrikaans. They considered teenage varieties as inappropriate language for handling such a serious matter. For health communication messages, White Afrikaans teenagers want, as one participant put it, "the language to be normal" (or, in other words, standard). Saal (2011) found among English teenagers a similar downgrading of teenage varieties in health messages.

What is interesting, is the fact that White Afrikaans teenagers did not perceive standard Afrikaans as being similar to the way they speak. In fact, the scores on the language similarity scale for both the teenage varieties and standard Afrikaans were at, or below, the scale's neutral midpoint, suggesting that neither one of the language varieties resembled the way in which White Afrikaans teenagers speak amongst themselves. Given that the salience of situational norms may have contributed to the dissimilarity and dislike of, specifically, the authentic teenage Afrikaans version, it is unclear why the teenagers also perceived standard Afrikaans as being dissimilar. Although White Afrikaans participants indicated that they did not perceive standard Afrikaans as being similar to their linguistic style, it does not imply that they had an overall dislike of standard Afrikaans. From the White Afrikaans participants' responses as to why they liked the standard Afrikaans version, it became apparent that the factor of intelligibility played a major role. White Afrikaans teenagers' overall unfavourable perception in respect of the three language varieties, and in particular standard Afrikaans, may have been related to the factor of AIDS fatigue. This general negative attitude towards HIV messages may have attributed to an overall unfavourable evaluation of (especially) the standard Afrikaans text version.

\subsection{Perceived image of the writer}

Coloured Afrikaans teenagers' positive perceptions of the use of their teenage Afrikaans in health messages did not have any effect on how they viewed the writer. In fact, Coloured Afrikaans teenagers have an overall positive and accommodating view of the writer, irrespective of the language variety used. Coloured Afrikaans teenagers view the writer (in all three language variety conditions) as a teenager or adult that is knowledgeable, experienced and caring, and someone they could befriend. White Afrikaans teenagers, however, have a less accommodating view of the writer. Although they tend to view the writer as an adult who is knowledgeable, experienced and caring, they are not keen to befriend him/her. Whether these evaluation patterns could be culture-orientated is an open question. Niedzielski and Giles (1996:338) argue that collectivistic cultures are more likely to accommodate than individualistic cultures. 
Although Coloured Afrikaans teenagers viewed their teenage Afrikaans favourably, it did not have any effect on the perceived image of the writer. It could be attributed to the nature of the topic, namely promiscuity: evaluations of the writer could have been the result of contentrelated cues rather than language cues (such as the teenage Afrikaans).

\section{Conclusion}

The findings of the study point towards a generally unfavourable view of the loveLife variety by both Coloured and White Afrikaans teenagers. For Afrikaans teenagers, the loveLife variety does not seem to be the variety of choice in the case of document-mediated HIV prevention messages. Among Coloured Afrikaans participants, there seems to be a positive evaluation and upgrading of their teenage Afrikaans. Therefore, when directing HIV messages at Coloured Afrikaans teenagers, the use of their teenage Afrikaans (with its affective-based nature) may be an effective way to address issues of a more serious, personal and emotional nature. For White Afrikaans teenagers, the use of teenage varieties to address serious issues such as promiscuity seems situationally inappropriate. As a general heuristic, the use of standard Afrikaans in health communication messages would seem to be the variety of choice for White Afrikaans teenagers.

\section{References}

Airhihenbuwa, C.O. 1995. Health and culture: Beyond the Western paradigm. Thousand Oaks, CA: Sage Publications.

Arthur, B., D. Farrar and G. Bradford. 1974. Evaluation reactions of college students to dialect differences in the English of Mexican-Americans. Language and Speech 17(1): $255-270$.

Bradac, J.J. and H. Giles. 2005. Language and social psychology: Conceptual niceties, complexities, curiosities, monstrosities, and how it all works. In K.L. Fitch and R.E. Sanders (eds.) Handbook of language and social interaction. Mahwah, NJ: Lawrence Erlbaum. pp. 201-230

Bresnahan, M.J., R. Ohashi, R. Nebashi, W.Y. Liu and S.M. Shearman. 2002. Attitudinal and affective response toward accented English. Language and Communication 22: 171185.

Burgoon, J.K. and J.L. Hale. 1987. Validation and measurement of the fundamental themes of relational communication. Communication Monographs 54(1): 19-41.

Burgoon, M. and J.T. Siegel. 2004. Language expectancy theory. Insight to application. In J.S. Seiter and R.H. Gass (eds.) Perspectives on persuasion, social influence and compliance gaining. Boston, MA: Pearson Education/Allyn \& Bacon. pp. 149-164.

Coupland, N., J. Coupland, H. Giles and K. Henwood. 1988. Accommodating the elderly: Invoking and extending a theory. Language in Society 17(1): 1-41.

De Klerk, V. 2005. Slang and swearing as markers of inclusion and exclusion in adolescence. In A. Williams and C. Thurlow (eds.) Talking adolescence: Perspectives on communication in the teenage years. New York: Peter Lang. pp. 111-127.

Den Ouden, H. and C. van Wijk. 2007. 'Om vet gaaf op te kicken': Over jongerentaal en het gebruik ervan in productadvertenties. Tijdschrift voor Communicatiewetenschap 35(3): 232-248.

Gallois, C., T. Ogay and H. Giles. 2005. Communication accommodation theory: A look back and a look ahead. In W.B. Gudykunst (ed.) Theorizing about intercultural communication. Thousand Oaks, CA: Sage Publications. pp. 121-148. 
Garrett, P., N. Coupland and A. Williams. 2003. Investigating language attitudes: Social meanings of dialect, ethnicity and performance. Cardiff: University of Wales Press.

Genesee, F. and R.Y. Bourhis. 1988. Evaluative reactions to language choice strategies: The role of sociocultural factors. Language and Communication 8(3/4): 229-250.

Giles, H. and A.C. Billings. 2004. Assessing language attitudes: Speaker evaluation studies. In A. Davies and C. Elder (eds.) The handbook of applied linguistics. Malden, MA: Blackwell. pp. 187-209.

Jacobs, J. 2009. Tienertaal. In D. Hugo (ed.) Halala Afrikaans. Pretoria: Protea Boekhuis. pp. 143-147.

Levine, S. and F. Ross. 2002. Perceptions of and attitudes to HIV/AIDS among young adults in Cape Town. Social Dynamics: A Journal of African Studies 28(1): 89-108.

Marais, S. and A. Coetzee. 2005. Tienerafrikaans. Tydskrif vir Taalonderrig 39(2): 244-259.

Nagtegaal, J. 2002. Daar's vis in die punch. Kaapstad: Tafelberg.

Niedzielski, N. and H. Giles. 1996. Linguistic accommodation. In H. Goebl, P.H. Nelde and Z.S.W. Wolck (eds.) Contact linguistics: An international handbook of contemporary research. Volume 1. Berlin: Walter de Gruyter. pp. 332-342.

Orme, J. and F. Starkey. 1999. Peer drug education: The way forward? Health Education 99(1): 8-16.

Probert Encyclopaedia - Online Slang Dictionary. [Online] Available: http://www.probertencyclopaedia.com/slang.html [Accessed 20 June 2006].

Saal, E.O. 2003. Die oorredende invloed van sleng en bron-ontvanger-ooreenkomste in MIV/vigs-materiaal. Tydskrif vir Nederlands en Afrikaans 10(1): 81-111.

Saal, E.O. 2008. The effect of language style in message-based HIV prevention. In P.H. Swanepoel and H. Hoeken (eds.) Adapting health communication to cultural needs: Optimizing documents in South African health communication on HIV and AIDS. Amsterdam: John Benjamins. pp. 129-149.

Saal, E.O. 2011. The effect of teenage language in health communication: A study among English and Sepedi teenagers. Language Matters 42(1): 83-103.

Saal, E.O. and J. Blignaut. 2011. "Moetie rai gammattaal gebrykie": Die gebruik en waarde van 'n Tienerkaaps in gedrukte advertensies. Litnet Akademies 8(3): 345-371.

Saal, E.O. and C.R. Fredericks. 2005. The persuasive effect of Tsotsitaal in HIV/AIDS material. Communicatio 31(2): 245-272.

Shisana, O., T. Rehle, L.C. Simbayi, W. Parker, K. Zuma, A. Bhana, C. Connolly, S.E. Jooste and V. Pillay (eds.) 2005. South African national HIV prevalence, HIV incidence, behaviour and communication survey, 2005. Cape Town: HSRC Press. [Online] Available: http://www.cadre.org.za/pdf/SA-National-HIV-Survey.pdf [Accessed 20 August 2006].

South African Concise Oxford Dictionary. 2002. Oxford: Oxford University Press.

Svenkerud, P.J. and A. Singhal. 1998. Enhancing the effectiveness of HIV/AIDS prevention programs targeted to unique population groups in Thailand: Lessons learned from applying concepts of diffusion of innovation and social marketing. Journal of Health Communication 3: 193-216.

Yzer, M. 2008. The integrative model of behavioral prediction and message-based HIV prevention. In P.H. Swanepoel and H. Hoeken (eds.) Adapting health communication to cultural needs: Optimizing documents in South African health communication on HIV and AIDS. Amsterdam: John Benjamins. pp. 49-69. 
Appendix 1: loveLife variety text (slang items are underlined)

\section{Getting around}

Why have one guy or gal when you can have many? It's about quantity, right?

WRONG. The days of the playa are over.

Some of us lurv to score. We mean sleeping with a hot new babe or guy every night, or trying to be a bigger playa than the rest of the crowd. But these games could land us in a pit of problems. You know that it will probably kill you as your chance of catching HIV/Aids skyrockets. Having one love is heaps better than being a playa.

Appendix 2: Standard Afrikaans text

\section{Rondslaap}

Hoekom slegs een kêrel of meisie hê as jy baie kan hê. Dit gaan mos oor getalle, nie waar nie? VERKEERD. Die dae van rondslaap is verby.

Sommige van ons hou daarvan om rond te slaap. Ons bedoel daarmee om elke aand met 'n ander seksueel aantreklike meisie of seun te slaap of om meer seksmaats te hê as die res van die groep. Maar hierdie speletjies kan vir ons ernstige probleme veroorsaak. Jy weet dit kan jou lewe kos, want jou kans om MIV/Vigs te kry skiet die hoogte in. Om een verhouding te hê, is baie beter as om verskillende seksmaats te hê.

Appendix 3: Authentic teenage Afrikaans texts

\section{(a) Authentic Coloured Afrikaans teenage variety}

\section{Rondbak}

Hoekom slegs een ou of dol hê as jy 'n gang kan hê. Dit gaan mos oor nommers, of hoe? WRONG. Die dae van rondbak is kla.

Sommige van ons like rondbak. Ons meen om elke aand met 'n different ntcha dol of ou te bak of om meer bakkers te hê as die res van die gang. Maar hierdie games kan vir ons serious problems gee. Jy weet dit kan jou sat maak, want jou kans om die Groot Siekte te kry is sky-high. Om een relationship te hê, is ntchaer as om different bakkers te hê.

\section{(b) Authentic White Afrikaans teenage variety}

\section{Rondraps}

Hoekom slegs een ou of chick hê as jy baie kan hê. Dit gaan mos oor hoeveel, of hoe? WRONG. Die dae van rondraps is klaar.

Sommige van ons like om rond te raps. Ons meen om elke aand met 'n ander sexy chick of ou te raps of om meer sex partners te hê as die res van die gang. Maar hierdie games kan vir ons serious problems gee. Jy weet dit kan jou lewe vat, want jou kans om Aids te kry is baie hoog. Om een relationship te hê, is cooler as om baie sex partners te hê. 